\title{
Du Bellay and the Inscription of Exile
}

\author{
MIRIELLA MELARA
}

I In Les Regrets Joachim Du Bellay uses the notions of exile and separation to articulate his position on the importance of invention and originality. ${ }^{1}$ Exile has to do with leaving one's "home," with distancing oneself from familiar and intimate surroundings. Exile may be a form of punishment or a condition imposed from an outside "authority." Self-imposed exile (that is, a desired physical/geographical or even ideological separation) is symptomatic of a need to differ and to negate (that which is being rejected or left behind). In Les Regrets, and even as early as Olive and La Deffence et illustration de la langue francoyse, Du Bellay expresses both a concern and fascination with exile and separation. In the Deffence he defines the Renaissance poet as a writer who is temporally exiled; the fate of the French poet is to be always, already separated from the ancient Greek and Latin masters (and thus from a period of literary excellence). “...tout ainsi que se feut le plus louable aux Anciens de bien inventer, aussi est ce le plus utile de bien immiter, mesmes à ceux dont la Langue n'est encor' bien copieuse \& riche." 2 Those who arrive too late must be satisfied to imitate.

Imitation brings little satisfaction to the poet interested in exploring the sources and limits of the poetic self in the face of a literary past that overwhelms him. "Les larges campaignes Greques et Latines sont déjà si pleines, que bien peu reste d'espace vide." 3 It is true that this passage ends on a rather pessimistic note, ${ }^{4}$ indicating that all attempts at finding a bit of this "espace vide" are perhaps futile. Reaching this untouched, empty literary space remains Du Bellay's goal nonetheless. But for Du Bellay, literary excellence (founding itself on invention and not imitation) is attainable through a series of "exiles" or what could be called "espacements." The desired "espace vide" seems only to be accessible (but there are no guarantees) if the poet "s'espace," if a space or separation exists between the poet and non-poets, the poet and his "home," the poet and his past or the poet and himself; that is, literary success seems ony to be possible if the poet is always, already "in exile." In Les Regrets, despairing over his so-called exile in 
Rome, the poet views writing as a way of shoring up spaces that separate and distance him from the things he cherishes and at the same time as a way of setting himself apart (filling in his own proper space) from a Ronsard (and other poets characterized by a style "haut" or "éloquent"). This very state of exile is the sine qua non for the writing project itself.

In the Deffence Du Bellay had already maintained that the act of writing requires a certain kind of "espacement" or separation on the part of the poet. The "don poétique" is necessary but not sufficient for poetic creation, thus the serious poet must separate himself from the comforts and distractions of life by laboring arduously over his verse, in the solitude and silence of his room. He should also be able to endure hunger, thirst and long hours without rest. The poet, "comme mort en soymesmes,"6 must deny the physical part of the self so that all attention may be focused on the creative faculties. He also needs to dedicate a significant part of his time to the study of ancient languages and texts. Finally, if the poet has been able to join successfully inspiration and art, his work will be considered qualitatively separate from the common; it will be "digne de l'immortalité." Creative success, therefore, is a function of the poet's ability to separate mind and body and to negate or exile one half of himself. ${ }^{7}$ The poet becomes a veritable writing machine that must distance itself from all interference. Although inspiration brings the first "impétuosité et ardeur d'écrire," there is nothing impetuous about the process of writing as it is viewed in the Deffence. Writing entails editing and re-editing and a constant manipulation of words and imagery; to write is to labor. Du Bellay is clearly concerned with the way the poetic self transforms itself into a written entity, the way the poetic voice "s'espace." ${ }^{8}$ Let us examine the means through which Du Bellay articulates space and writing in Les Regrets in his attempt to stake out his own poetic territory.

In Les Regrets this linguistic "working through" or refinement is no longer as important because a different esthetic takes its place. Indeed, place itself is an important issue in Les Regrets for Du Bellay makes explicit the fact that he is writing from a new location, from the very city that must compel him to confront the presence/absence of the ancients with graphic vividness. Although the monuments lay in ruin, the texts outlast the destruction of time and thus keep alive the spirits of the literary masters. ${ }^{9}$ And no matter how crowded this "campaignes" of books seems to be, that which is not to be found there is Du Bellay himself, that is to say, his story, the representation of his poetic self. The Roman experience, that is, the experience of physical exile serves as the "pretext" to the questioning of that poetic self, a questioning of what that self could be if it were to be defined by different circumstances and 
if the past that structures and determines it were to be de-emphasized or even negated. ${ }^{10}$ In attempting to define his own small space within literary tradition, Du Bellay stakes out an 'autobiographical' writing space. The term 'autobiography' is not used here in the very narrow, prescriptive sense of a Philippe Lejeune for example. ${ }^{11}$ Les Regrets is auto-biographical because through its sonnets emerges a "graphic"12 representation of a poetic self (even if the life of that self is radically reduced to a negation or a "refus"). The "I" is translated/sublated into the written "matter" of the work. Instead of a story of a life we find a story of writing: ${ }^{13}$ the poet continually points to a certain process that he will follow in his "new" poetry. As Floyd Gray explains,

Du Bellay n'est jamais immergé dans le sujet du moi; il s'en détache pour le contempler à une certaine distance, comme une écriture à accomplir...il reste en deça de son sujet, c'est-à-dire qu'il glose la manière dont il va le traiter, mais sans y pénétrer: il fait d'avance le procès de ce qu'il ne fera pas. ${ }^{14}$

The "moi" therefore is always deferred; writing can never "capture" it or coincide with it but the poet writes himself ("s'écrit") nevertheless. Du Bellay takes to the extreme the Montaignian predicament (and indeed the predicament of all representations of the self):

Je ne me tiens pas bien en ma possession et disposition. Le hasard y a plus de droict que moy...je ne me trouve pas ou je me cherche; et me trouve plus par rencontre que par l'inquisition de mon jugement. ${ }^{15}$

The "I" too is seen as a process, that is to say as a writer in process, observing and questioning himself and his "métier" through his writing.

Du Bellay concludes in Les Regrets that his former self no longer exists; forced to live and work in Rome, he has forsaken his language, his vocation, his home and friends. He has no choice but to speak Latin, "changeant à l'estranger mon naturel langage...afin d'estre entendu..."16 Even Ovid, he points out, (whose influence throughout Les Regrets has been well documented) was obliged to adopt another language in exile. "Qui me pourra reprendre...?" $(10,68)$ Seeing himself as a virtual prisoner in a foreign land (that is, exiled at the hands of an 'authority' beyond his control), Du Bellay's very definition of himself has changed:

Ton Du Bellay n'est plus. Ce n'est plus qu'une souche Qui dessus un ruisseau d'un doz courbé se couche, Et n'a plus rien de vif, qu'un petit de verdeur.(21,86) 
He also arrives at the conclusion that he can never again be the poet he once was: "Et que ce que j'estois, plus estre je ne puis,/ Aiant perdu mon temps, \& ma jeunesse encore." $(42,110)$ A splitting or separating of the self has occurred between Du Bellay-past and Du Bellay-present. ${ }^{17}$ When addressing "marastre nature" the poet asks: "Pourquoy ne m'as tu fait de moymesme le maistre,/ Pour suivre ma raison et vivre du tout mien?" $(45,113)$ Not being master of oneself implies that one is out of control, out of one's own control, or "hors soi." This feeling of being outside of oneself may be closely linked to the fact that he is outside of his native territory, outside the very language that defined his poetic vocation. The lord has become vassal.

Maintenant la Fortune est maistresse de moy, Et mon coeur qui souloit estre maistre de soy, Est serf de mille maulx \& regrets qui m'ennuyent. $(6,62)$

At times it would even seem that being "maître de soi" is a function of whether or not one is "chez soi."

$\mathrm{O}$ qu'heureux est celuy qui peult passer son aage

Entre pareils à soy! \& qui sans fiction,

Sans crainte, sans envie, \& sans ambition

Regne paisiblement en son pauvre mesnage!...

Son principal espoir ne depend que de luy,

Il est sa court, son roy, sa faveur, \& son maistre... $(38,106)$

It is this positing of a divided and dependent self that puts into question the very definition of the poetic self and of his vocation. If he cannot be his own master he will ultimately claim not to need or want any; he will claim to exile himself from all poets and texts. As we shall see, Du Bellay's Regrets can be read as an attempt to re-establish a certain "maîtrise" of the self on foreign territory where past rules and truths no longer apply.

For Du Bellay, writing and developing poetry (in one's own tongue) is tantamount to acquiring the nurturing and growth attainable only "at home." Great poetry (the kind that is "digne de l'immortalité" and possible only for the past Du Bellay) can only be written "at home" for it is in this spiritual and physical place that the poet is unified in body and soul, soil and tongue, and given the proper environment in which to create and be properly rewarded. 
Ce pendant que la court mes ouvrages lisoit, Et que la soeur du Roy, l'unique Marguerite, Me faisant plus d'honneur que n'estoit mon merite,

De son bel oeil divin mes vers favorisoit, Une fureur d'esprit au ciel me conduisoit D'une aile qui la mort \& les siecles evite, Et le docte troppeau qui sur Parnasse habite, De son feu plus divin mon ardeur attisoit. Ores je suis muet, comme on voit la Prophete Ne sentant plus le Dieu, qui la tenoit sujette, Perdre soudainement la fureur \& la voix.

Et qui ne prend plaisir qu'un Prince luy commande?

L'honneur nourrit les arts, \& la Muse demande

Le theatre du peuple, \& la faveur des Roys. $(7,64)^{18}$

Living away from home brings a sense of loss and, ultimately, fragmentation and disillusionment because the poet's creative "environment" has changed. Du Bellay would like to maintain that there exists a certain "identité à soi" and virtuosity possible only in one's own language, in one's own home; one cannot properly "be oneself" without it. His poetic endeavor in Les Regrets may indeed be viewed as a continual effort to feel "at home." 19 Existing outside of its milieu, the self is posited as autonomous and free to define itself in its own tongue, according to its new "circumstances." The poet in fact represents himself as a victim of circumstance:

Si je n'ai plus la faveur de la Muse,

Et si mes vers se trouvent imparfaits,

Le lieu, le temps, l'aage ou je les ay faits,

Et mes ennuis leur serviront d'excuse.(46)

Claiming to be the homeless and museless poet, Du Bellay will attempt to inscribe his autograph in a place that already bears too many names and too many traces of the past. The poet himself is a product of those past incriptions. As Floyd Gray observes, "Le je qui parle est un leurre puisque tout imprégné des écrits qui le déterminent." ${ }^{\prime 2}$ Nevertheless, the exiled poetic self proceeds as if he were unique.

In Rome Du Bellay clearly experiences a nostalgia for a lost period of human excellence. The "new" Rome, the "siège de l'Eglise," is defined by vice and corruption and, in the "old" Rome, the great monuments of the past resemble "un grand monceau pierreux." $(80,155)$ The great masters have given way to the great liars and flatterers and Rome's impressive 
monuments are crumbling into indistinguishable pieces of rock. ${ }^{21} \mathrm{Du}$ Bellay shows in Les Antiquitez that to look at Rome is to look upon a funerary monument:

Rome n'est plus, et si l'architecture

Quelque umbre encor de Rome fait revoir,

C'est comme un corps par magique scavoir

Tiré de nuict hors de sa sepulture.(5,278)

The remaining architectural monuments function as the memory traces of that unattainable past. By confronting the Roman ruins, the Roman sepulture, one is compelled to recall one's own mortality and call into question the possibility of immortality. If the great and strong can fall so quickly what can be said of the weak and powerless? And literary monuments, are they not as fragile as the architectural ones since decay and destruction are inevitable?

In Les Antiquitez Du Bellay cites one exception to time's destruction: writing. Writing is viewed as a vehicle for the resurrection of dead spirits and forgotten memories. The written word may be copied and disseminated and is in fact more "resistant" than Rome's monuments. ${ }^{22}$

Le corps de Rome en cendre est devallé,

Et son esprit rejoindre s'est allé

Au grand esprit de ceste masse ronde.

Mais ses escripts, qui son loz le plus beau

Malgré le temps arrachent du tumbeau,

Font son idole errer parmy le monde. $(5,278)$

Writing, for Du Bellay, has the power to resurrect that which is nonmaterial (i.e. "loz") and therefore enduring. Writing is at the same time corporality (of the letter) and spirituality (of the meaning). The "graphic" sign is both body and spirit and the activity of writing, in and of itself, performs a life-giving and life-sustaining process. Writing gives life to that which is being represented/resurrected as well as to the poet himself. It is with this view of writing that Du Bellay attempts to re-appropriate the poetic self.

In Les Regrets he specifically designates his writing project as a journal - that is, mere notations of and comments on lived experience. Disguises and "riche peinture" veil and postpone the truth while spontaneity and immediacy guarantee it. ${ }^{23} \mathrm{He}$ defines his writing as something random and aimless; it supposedly has no pre-determined course: “j'escris à l'adventure." $(1,54)$ But what kind of poetry would that be? 
Comme de l'arbre on voit naistre le fruict, Ainsi les fruicts que la douleur produict Sont les souspirs et les larmes non feinctes.(51)

His argument could be summarized as follows: Just as the tree bears fruit (naturally), the poet's pain will produce true, poetic lamentations embodied in verbalized regrets. These products are "non feinctes" by virtue of the fact that they originate from pain and are the manifestations and the reactions of passion. "Je me contenteray de simplement escrire / Ce que la passion seulement me fait dire." $(4,59)$ Poetry seems to be placed on an equal level with passion, that is, with the immediate, human and corporal suffering. To speak of passion, is also to evoke the idea (originating from a common root) of passivity. The poet is "affected" by his passion - he is "impressed" by it. $\mathrm{He}$, in turn, translates or sublates that passion into linguistic form and continues the inscription process. Passivity/passion is transformed into activity. Du Bellay's new source of inspiration (what he calls "une fureur plus basse") could not be further divorced from the divine and the rarefied. Poetic writing is interwoven in a cause and effect relationship with life and passion. ${ }^{24}$ Michel Deguy offers the following remarks:

...par ce pleur, en tant que ce pleur, le poétique n'est plus la rareté, mais le chant encore, un nouveau chant "jour et nuit," inmanquable. Toute heure étant lamentable est pour le poème; la poésie est entrée dans une nouvelle égalité à la vie. En renonçant à l'exception, il voit se reformer comme nouvel élément de la navigation poétique l'entier du vivre en tant que déserte de la muse. ${ }^{25}$

It is clear that this conception of poetry is based on naiveté, a topos valorized by the Pléiade. Naiveté was not only a quality of the best poetry - naturalness, spontaneousness, and rightness - but also the very essence of language which could only be fully exploited by native speakers. ${ }^{26}$ It is a quality held up in opposition to imitation and artificiality. Although it is evident that Du Bellay, in the sections quoted above, is simply "borrowing" from accepted dogma, it can also be said that he is attempting to take naiveté to the extreme. He plays with the idea that the notion of "the natural" taken to the extreme may be a type of "gut-level" reaction or expression through words that do not need to be embellished, re-arranged, or re-thought. ${ }^{27}$ True pain cannot be feigned; its manifestation cannot be repressed or mediated and the regret is thus the most sincere of expressions. This claim cannot be taken seriously by the reader since the medium itself negates any attempt at immediacy and, as François Rigolot points out, “...il s’agit moins pour lui de rechercher un degré zéro du 
style que de cultiver, consciemment, un style de dégre zéro." 28 As Du Bellay explains (and perhaps warns) in the last half of his work: "L'artifice caché, c'est le vray artifice." $(142,217)$

Along with this affected naiveté or modesty comes a daring declaration from our poet:

Et peult estre que tel se pense bien habile,

Qui trouvant de mes vers le ryme si facile,

En vain travaillera, me voulant imiter. $(2,56)$

He claims to be inimitable and, consequently, will leave no model or example for others to follow. ${ }^{29}$ By declaring that he is inimitable he announces his desire to free himself from paradigms. It is interesting to note that, following this bold statement, any referral to outside texts is flatly rejected:

Je ne veulx feuilleter les exemplaires Grecs, Je ne veulx retracer les beaux traicts d'un Horace, Et moins veulx-je imiter d'un Petrarque la grace, Ou la voix d'un Ronsard, pour chanter mes regrets. (4.59)

Neither contemporary nor ancient poets shall be read or imitated. Du Bellay is in fact denying the validity of (outside) textual authority of any kind. He is his own proper authority in his exile and in his "malheur." His literary "debts," expecially in Les Regrets, are well documented. ${ }^{30}$ But in Les Regrets he chooses to minimize the importance of that influence and claims not to seek out other "authorities." This we may interpret as self-imposed exile since he now wishes to separate himself from other poets through his new pedestrian "esthetic."

It has been said that this attempt to deny authority is at the very core of the autobiographical project. Jean-Luc Nancy, in discussing the autobiographical enterprise in Descartes, offers the following elucidation:

Autobiography is the necessary genre for whoever renounces all teaching authority (all truth that is taught from a position of authority, that in short is taught, in other words comes from the outside to a "subject")... ${ }^{31}$

Models, influences, authorities are withdrawn, not in order to pose a new paradigm, but simply to present the expressly humble, contingent, imprinted/ imprinting poetic self. Paradigms are removed so that the frank, unfeigned truth may (supposedly) manifest itself. He requires neither muse nor model 
for his project. In the scenario Du Bellay has set up, the regrets or ennuis are not to be considered as expositions of a "truth," they are the sum total of his truth. Judge me by what I have written, we can hear him say, for my words are the only life I have left, they are my life. They allow me to be "myself," to be "chez moi," to declare my own law.

Asseure toy Vineus que celuy seul est Roy, A qui mesmes les Roys ne peuvent donner loy, Et qui peult d'un chacun à son plaisir escrire. $(42,110)$

The establishment of the "chez soi" in a foreign land, in Les Regrets, implies the negation of all that is now viewed as being "autre" and therefore threatening.

Du Bellay's attempted "maîtrise" over his poetic kingdom can be seen in an interesting and almost magical light when one notes the way he plays with the words "chanter" and "enchanter:"

Si ne veulx-je pourtant delaisser de chanter,

Puis que le seul chant peult mes ennuys enchanter...

$(11,70)$

Je ne chante (Magny) je pleure mes ennuys, $\mathrm{Ou}$, pour le dire mieulx, en pleurant je les chante, Si bien qu'en les chantant, souvent je les enchante: Voila pourquoy (Magny) je chante jours et nuicts. $(12,71)$

There is of course an etymological link between "cantare" and "incantare" 32 but to comprehend this word play one must notice that "chanter" is also introduced in comparison to "pleurer." The acts in fact overlap such that "chanter" is no longer distinct from the emotive investment associated with "pleurer." "Toute heure étant lamentable est pour le poème," Deguy has pointed out. "Je chante jours et nuicts" says the poet directing us toward that union between poetry and the poet's experience of his own condition. Verse is sung night and day because there is no rest from suffering and (the writing and singing) of verse is the only solace available to the poet. Verse is repeated or continued "jours et nuicts" much like the chants performed in religious or occult ceremonies. The poet's verse is rendered enchanted through repetition-poetry becomes incantation. Floyd Gray observes that instead of abandoning himself to the "enchante- 
ment" possible through the "chant," Du Bellay simply plays on the word "chant:"

la séduction opère donc uniquement sur le plan de l'écriture...En s'efforçant d'exprimer pleinement la signification qu'il attribue au mot "chant," Du Bellay finit par lui enlever toute résonance poétique et musicale. Le chant contient, dans son optique, un coefficient négatif: il égale plainte qui égale regret. ${ }^{33}$

Negative perhaps, but essential nonetheless for the "chant" is the exteriorization of the regret and the musicality sought after in Les Regrets will be purposefully banal. According to Gray, Du Bellay denies the magical power of poetry precisely by contenting himself with pedestrian rythms and images. His simple rhymes eliminate all musicality and surprise. "De telles rimes n'ont aucun pouvoir d'enchantement..."34 Poetry that relies heavily on anaphora, as is the case with Les Regrets, is perhaps less than eloquent but is not necessarily lacking in musicality. For Gray however, "Les répétitions qui, dans une litanie, auraient des vertus poétiques, ne font ici que limiter le cercle de rayonnement du sonnet." 35 I would argue that repetition, on the level of the "chant," offers a definite but limited musicality; it could be better characterized as a "degré zéro" musicality: the repetition of the same beats and rhythms, the same laments. The musicality becomes as pedestrian as the subject matter and the "vertus poétiques" can be found in repetition and in the familiarity of sameness. Since repetition is the key term here we must turn to Echo for help in this discussion.

This poet in exile is left with only a continual confrontation with his own voice - a voice inspired by him and perpetually redirected back to its source. When calling out to his absent "mère des arts" he obtains but one reply: "Mais nul sinon Echo respond à ma voix." $(9,66)$ Echo assures the existence of his poetic voice by virtue of an auto-affection. I sing therefore I am. But the echoed voice is both the mere duplication of the same voice as well as the return of a different voice. "Echo 'répète' et fissure le simple en sa duplicité," remarks Deguy. ${ }^{36}$ The tail ends of utterances are returned so that they themselves take on new meaning and seem to declare an autonomous existence. Our poet/Narcissus could not have found a better companion in exile. Echo, condemned by the gods to a life of terrestrial suffering, also survives through a negativity. Manifesting her existence by doubling the voices of others, she points to the potential play inherent in language ("jeu de mots" as well as "jeu de sons"). Echo changes/translates the sounds that she manipulates. Repetition allows for the layering of meaning. She offers the possibility 
of an escape from the confining limits of context by the liberating power of repetition, a power of enchantment. This enchantment brings about a transcendence of experience whose power emanates from the poetic subject himself. The poetic message is somehow charmed such that the condition being lamented becomes not only tolerable but a source of power and creative productivity. It is as if the poet himself is now the source of his own inspiration. The "chant" has the power to negate and transcend terrestrial suffering.

Ainsi chante l'ouvrier en faisant son ouvrage,

Ainsi le laboureur faisant son labourage,

Ainsi le pelerin regretant sa maison...(12,71)

Paradoxically, the repetitive lamenting of one's condition can bring solace and relief because repetition allows a momentary separation to take place: the poet temporarily exiles himself from his condition through his verse. This is of course not the first time the therapeutic powers of poetry have been explored. Since "le métier de la lyre" has traditionally been associated with poverty (as opposed to the riches of the "courtisan"), poetry was said to offer solace from the lack of material comforts. But poverty and misery were made tolerable precisely because the Muses offered comfort. Even Ovid in the Tristia had a Muse by his side:

Therefore because I continue to live and resist my harsh fortunes / And a complete disgust for this worrisome life does not depress me / I am grateful, my Muse, to you because you offer me solace, / Rest and release from care, medicine for my veins.(IV, 10) ${ }^{37}$

Du Bellay, positing that he has no Muse, makes himself responsible for his own "salvation" through writing and effectuates his "maîtrise" over the self.

The "espace vide" that Du Bellay stakes out in Les Regrets is of course far from empty. The Muses may have retreated but the voices and traces of the past have not. Denying the existence (or perhaps the clarity and loudness) of those voices, our poet claims to hear only his own voice. Seeing himself as temporally and geographically exiled, Du Bellay redefines the poetic enterprise precisely because adversity and "mauvaise fortune" redefine the circumstances upon which the poetic self is founded. Separated from friends, home, language, prince and public, the poet will ultimately succeed in using the very notions of exile and separation to his advantage. Desiring to make himself "at home," to define his own literary territory, Du Bellay attempts to make valid his own authorial authority through so-called self-inspired and 
unmediated verse. He thus further exiles himself from his peers by claiming to be inimitable. The "I" in Les Regrets emerges as a self-reflective writing subject whose seemingly pedestrian "substance" is undermined by its ability to elude the reader and thus declare a certain power or mastery of its own. The poet, therefore, succeeds in exiling himself within the very graphesis of the work. The poetic "I" in Les Regrets, although reduced to a mere negation or refus, is made up of an interesting and complex system of deferrals and comparisons that maintain the life of that "I" because it is in the process of developing and questioning its identity. In the case of this poetic subject, the answer to the question "que suis-je?" can only be "celui qui s'écrit."

\section{University of Nevada, Reno}

\section{Notes}

1. Grahame Castor points out that, although the word "originality" is used by critics in reference to Renaissance authors, it "did not become the antonym of imitation until the seventeenth century." [Pléiade Poetics, (Cambridge: Cambridge University Press, 1964) 5]. "Original" was normally used as a noun, and was the antonym of "copie." "Both in translation and in imitation the poet is drawing upon other authors for his material. When he invents, on the other hand, he is relying entirely upon himself. $\mathrm{He}$ becomes the first to tread a particular poetic path, and all credit and honour are due to him for that primacy."(115, my emphasis)

2. Quoted by Margaret Ferguson in her study, "The Exile's Defense: Du Bellay's La Deffence et illustration de la langue francoyse." Ferguson observes that Du Bellay painfully considers himself to be a "late comer," separated from the invention possible only by "les premiers." [PMLA 93,2 (March 1978), 280.]

3. Joachim Du Bellay, La Deffence et illustration de la langue francoyse, ed. Henri Chamard (Paris: Librairie Marcel Didier, 1966), 190.

4. Ferguson, "The Exile's Defense," 278.

5. We may even say that the belief in divine inspiration and fury is itself a way of locating the poet "out in space," outside of the mainstream, his ear turned to the daughters of Memory. According to Grahame Castor, the theory of divine inspiration which lies behind the Pléiade's view of the poet and his work "is a theory which recognises the poetic activity as being essentially different from other forms of mental and communicative activity... The poetic fury is a 'ravissement,' it comes from outside the poet and it sweeps him along with it; and it enables him to go beyond the normal range of his mental powers." (Pléiade Poetics, 36)

6. Du Bellay, Deffence, 105-106.

7. Marie-Dominique Legrand sees the following relationship between poetry and exile: "Ainsi délocalisé dans le temps, l'exil apparaît comme inhérent à l'expérience poétique et l'expérience biographique n'est plus qu'accidentelle: le 'Superbe rivage' du Tibre chanté au sonnet 10 peut aussi bien être celui de la Seine, et le retournement qui, au 
sonnet 130 , reconnaît Paris comme nouveau lieu d'exil jusqu'à lui faire regretter Rome...fonde la métaphore du poète nécessairement exilé. Nécessairement la poésie exile." (“Exil et Poésie: les Tristes et les Pontiques d'Ovide, les Soupirs d'O. de Magny, Les Regrets de J. Du Bellay," Littératures, 17 (1987), 43.

8. I am drawing here from Jacques Derrida's discussion of writing, most notably in "Freud et la scène de l'écriture": "Le propre de l'écriture, nous l'avons nommé ailleurs, est en un sens difficile de ce mot, espacement: diastème et devenir-espace du temps..." L'écriture et la différence (Paris: Editions du Seuil, 1967), 321. The notion of espacement or spacing necessarily includes pauses, blanks, punctuation, etc. which are integral to the process of signification.

9. I would have to disagree with Floyd Gray here when he states that "Rome lui offre l'image d'une poésie noble, mais stérile, condamnée d'avance à l'échec. Poésie mimétique plutôt que visionnaire, visant à faire revivre une grandeur passée dans un présent d'écriture..." La Poétique de Du Bellay, (Paris: Librairie Nizet, 1978), 163. Du Bellay had explained in the Deffence that a poet cannot recapture the "première grandeur et excellence" of the ancient poetry by attempting to re-assemble discarded fragments. He does not want to revive this past, but is very much aware of the power of texts in general to revive. Margaret Ferguson has this to say about Du Bellay's relationship with his past: "Imaginative difficulties arise for Du Bellay because he cannot fully accept restoration as a natural or legitimate process. If the ancients are felt to be still alive, one cannot propose to give them a new birth without some uneasiness..." ("The Exile's Defense," 277)

10. "Le déplacement dans l'espace se traduit par l'éloignement de l'inspiration, c'est-àdire par un sentiment de perte qui est une des sources les plus génératrices de 'regrets." (Gray, La Poétique de Du Bellay, 64.)

11. See Le pacte autobiographique (Paris: Editions du Seuil, 1975).

12. For the word "graphic" I am using the following interpretation given by Marie-Rose Logan in her article "Graphesis..." appearing in Yale French Studies, 52: “"Graphesis' de-scribes the action of writing as it actualizes itself within the text independently of the notion of intentionality."(12)

13. "Le 'Je' qui s'exprime dans Les Regrets serait donc moins un 'Je-personnel' qu'un 'Je-fait livre'..." (Legrand, "Exil et poésie," 45.)

14. Gray, La Poétique de Du Bellay, 64 et 66.

15. Michel de Montaigne, Essais, 2 vols. (Paris: Editions Garnier Frères, 1962), 1: 37.

16. Joachim Du Bellay, Les Regrets et Autres Oeuvres Poétiques, ed. J. Joliffe \& M.A. Screech (Geneva: Droz, 1966), Sonnet 10, p. 68. Henceforth all page references to this text will appear directly in the body of the article.

17. Not everyone is in agreement about the status of this poetic self. Referring to $\mathrm{Du}$ Bellay's frequent comparisons with other poets Gray makes the following remarks: "Le moi que Du Bellay prétend nous livrer est fragmenté par la comparaison qu'il ne cesse d'établir entre lui-même et d'autres poètes, c'est-à-dire par une poétique qui ne parvient à se réaliser que par la voie de l'analyse." La Poétique de Du Bellay, 60. 
François Rigolot concurs when he states that "plus le moi est faible, plus il a besoin de s'identifier à des objets extérieurs, ne serait-ce que pour se rassurer sur son existence." Le Texte de la Renaissance (Genève: Librairie Droz S.A., 1982), 217. Richard Katz, however, interprets the poet's position in this way: "It is clear that Du Bellay refuses many things - his antihyperbolism, his fondness for negative anaphora, for example,... - but the 'faible moi' is merely a pose, masking an essentially strong, assertive persona." The Ordered Text: The Sonnet Sequences of Du Bellay (N.Y.: Peter Lang, 1985), 209.

18. When commenting on the last three lines of this sonnet, Katz has this to say about $\mathrm{Du}$ Bellay's ironic stance: “...the source of the 'furor poeticus' is not divine but strictly sub-lunary: it is public, and particularly royal favor that 'nourishes' art." (The Ordered Text: The Sonnet Sequences of Du Bellay, 108.) And we could also add that this type of favor nourishes the poet as well but one must be "at home" in order to receive it.

19. It may indeed be said that one is never completely "at home" within language. It is the nature of language to mediate and postpone through endless tropological voyages. The "I" can never "coincide" with its representation. Rosamond Bovey translates this "homesickness" into very economic and practical terms in her article, "Joachim Du Bellay's Regrets and the Satire of the Poet," in L'Esprit Créateur, 19.3 (Fall 1979). Bovey contends that the poet's nostalgia is primarily motivated by the desire for the favor and support of the French Court - a thing regretfully inaccessible in Rome. And, as we know from the end of Les Regrets, being "back home" led to more disharmony and artifice than unity and naturalness. For this reason Ferguson reads the "home" as "a relational, rather than an essential concept. The home is always defined negatively: it is that which one does not now possess...the closer he gets to it, the more it looks like the very place from which he is fleeing." ("The Exile's Defense," 277)

20. La Poétique de Du Bellay, 65.

21. Gilbert Gadoffre reminds us that no excavations of the city had taken place at that time. Du Bellay et le Sacré (Paris: Editions Gallimard, 1978), 48.

22. Copies of certain sonnets that would later be part of Les Regrets were in fact being circulated without Du Bellay's permission. "Beaucoup de ces sonnets circulaient déjà en manuscrit; d'autres avaient été imprimés sans la permission du poète, qui avait dû intenter des procès à plus d'un imprimeur." (commentary by Screech in Du Bellay, Les Regrets, 10.)

23. As Screech points out: "Du Bellay présente ces sonnets comme des simples histoires; les 'Diaria' et les 'Commentaires' passaient pour les plus humbles formes du genre historique, aux antipodes de la poésie 'menteuse."” (55)

24. "...exilé physiquement, il se rapatrie linguistiquement, retrouvant dans les mots familiers une garantie d'authenticité." (Gray, La Poétique de Du Bellay, 101.)

25. Michel Deguy, Tombeau de Du Bellay (Paris: Editions Gallimard, 1973), 82.

26. Castor, Pléiade Poetics, 81.

27. In the Tristia Ovid had also claimed not to have made any corrections to his verses, thereby rendering them more "natural." 
28. Rigolot, Le Texte de la Renaissance, 215.

29. But with these very words, Screech believes, Du Bellay clearly shows that he would like to be considered Horace's successor as satirist because he simply rephrases Horace's very words and indeed proceeds to write satire rivaling his precursor. (Du Bellay, Les Regrets, 21)

30. This gesture of denial and separation from his literary fathers and brothers is clearly a rhetorical claim for the autonomy of the self and for his authorial authority. Du Bellay certainly cannot divest himself of his literary influences simply by dismissing a few proper names. As Joseph Vianey points out in his study entitled Les Regrets de Du Bellay, “...nous avons le droit sans doute de nous demander si Joachim Du Bellay aurait chanté ses regrets sans l'exemple d'Ovide, s'il aurait fait ses sonnets en alexandrins sans l'exemple de Ronsard, si sa satire aurait eu tant de mordant sans l'exemple de l'Arioste et de Berni, s'il aurait, sans l'exemple de Berni, construit le sonnet comme il le fait." (Paris: Librairie Nizet, 1967), 89.

31. Jean-Luc Nancy, "Mundus est fabula," Modern Language Notes, 95 (1978), 644.

32. "Remarquons que le jeu de mots "chant" - "enchanter," conforme au goûts de l'époque, n'est guère plaisant; il a pour but de faire ressortir le sens étymologique de mot "chant." (commentary by Screech in Les Regrets, 70)

33. Gray, La Poétique de Du Bellay, 71.

34. Gray, La Poétique de Du Bellay, 73.

35. Gray, La Poétique de Du Bellay, 75.

36. Deguy, Tombeau de Du Bellay, 74.

37. Ovid, Tristia, trans. L.R. Lind, (Athens: University of Georgia Press, 1975), 116. 